\title{
Redox Reactions of Water Soluble N-Methylated PV Octa(2-pyridyl) corrolazine with Sodium Dithionite and Cobalamins
}

\author{
Denis S. Salnikov, Svetlana S. Ivanova, and Pavel A. Stuzhin ${ }^{@}$
}

Dedicated to Professor Rudi van Eldik on the occasion of his $75^{\text {th }}$ Birthday

Research Institute of Macroheterocycles, Ivanovo State University of Chemistry and Technology, 153000 Ivanovo, Russia

@Corresponding authorE-mail: stuzhin@isuct.ru

\begin{abstract}
Corrolazine macrocycle in soluble $P^{V}$ complex of $\mathrm{N}$-methylated 2-pyridyl substituted derivative $\left[\left(\mathrm{Me} \mathrm{P}^{+} \mathrm{Py}\right)_{8} \mathrm{CAP}(\mathrm{OH})_{2}\right]$ can be reduced reversibly by dithionite affording consecutively anion-radical $\left[\left(\mathrm{Me}^{+} \mathrm{Py}\right)_{8} \mathrm{CAP}(\mathrm{OH})_{2}\right]^{\bullet-}$ and $\pi$-dianion $\left[\left(\mathrm{Me}^{+} \mathrm{Py}\right)_{8} \mathrm{CAP}(\mathrm{OH})_{2}\right]^{2-}$. Treatment of $\left[\left(\mathrm{Me}{ }^{+} \mathrm{Py}\right)_{8} \mathrm{CAP}(\mathrm{OH})_{2}\right]$ with super-reduced cobalamin [Cbl(I)] leads directly to $\pi$-dianion, which can reduce aquacobalamin $\left[\left(\mathrm{H}_{2} \mathrm{O}\right) \mathrm{Cbl}(\mathrm{III})\right]$. The central dihydroxophosphonate moiety in $\left[\left(\mathrm{Me}^{+} \mathrm{Py}\right)_{8} \mathrm{CAP}(\mathrm{OH})_{2}\right]$ undergoes two-stage acid ionization in basic medium.
\end{abstract}

Keywords: Water soluble corrolazines, acid-base interaction, dithionite, cobalamins, ox-red reactions.

\section{Водорастворимый $\mathrm{P}^{\mathrm{V}}$ комплекс $\mathrm{N}$-метилированного окта(2-пиридил)корролазина: окислительно-восстановительные реакции с Аитионитом натрия и кобаламинами}

\author{
А. С. Сальников, С. С. Иванова, П. А. Стужин ${ }^{\circledR}$ \\ НИИ химии макрогетероциклов, Ивановский государственный химико-технологический университет, 153000 \\ Иваново, Россия \\ ${ }^{\circledR}$ E-mail: stuzhin@isuct.ru
}

\begin{abstract}
Водорастворимый комплекс фосфора(V) с $N$-метилированным 2-пиридилзамещенным корролазином $\left[\left(\mathrm{Me}^{+} \mathrm{Py}\right)_{8} \mathrm{CAP}(\mathrm{OH})_{2}\right]$ обратимо восстанавливается дитионитом натрия в щелочной среде, последовательно образуя анион-радикал $\left[\left(\mathrm{Me}^{+} \mathrm{Py}\right)_{8} \mathrm{CAP}(\mathrm{OH})_{2}\right]^{\bullet-}$ и $\pi$-дианион $\left[\left(\mathrm{Me}^{+} \mathrm{Py}\right)_{8} \mathrm{CAP}(\mathrm{OH})_{2}\right]^{2-}$. При взаимодействии с супервосстановленной формой кобаламина [Cbl(I)] сразу же образуется $\pi$-дианион, который восстанавливает

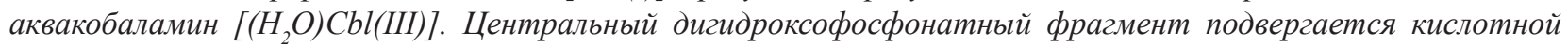
ионизачии в щелочной среде.
\end{abstract}

Keywords: Водорастворимые корролазины, кислотно-основное взаимодействие, дитионит, кобаламины, окислительно-восстановительные реакции. 
Corrolazines $(C A)$ are analogs of porphyrazines $(P A)$ containing contracted macroheterocycle consisting of dipyrrolyl fragment, one pyrrole and one pyrrolenine rings joined by three bridging meso-nitrogen atoms (Chart 1). ${ }^{[1,2]}$

Complexes of corrolazines containing $\mathrm{P}^{\mathrm{V}}$ as a central atom are easily available by reaction of the corresponding metal free porphyrazines with phosphorus(III) halides in pyridine. In such way the corresponding $\mathrm{P}^{\mathrm{V}}$ corrolazines were obtained from variously substituted phthalocyanines ${ }^{[3]}$ tetrapyrazinoporphyrazines ${ }^{[4]}$ and aryl substituted porphyrazines. ${ }^{[5]}$ The contraction of the porphyrazine macrocycle requires the reductive conditions, and complexes of tetrabenzo fused corrolazines $(T B C A)$ with $\mathrm{Si}^{\mathrm{IV}}, \mathrm{Ge}^{\mathrm{IV}}, \mathrm{Al}^{\mathrm{III}}$ and $\mathrm{Ga}^{\mathrm{III}}$ can be prepared from the corresponding metal phthalocyanines in the presence of reductants $\left(\mathrm{NaBH}_{4}\right.$, $\left.\mathrm{Mg} / \mathrm{Alk}_{3} \mathrm{SiCl}\right) \cdot{ }^{[6-9]}$ Non-metalated $T B C A$ and its complexes with other metals are not-known, but $\mathrm{P}^{\mathrm{V}}$ complexes of octaaryl substituted corrolazines can be reductively dephosphorylated $\left(\mathrm{Na} / \mathrm{NH}_{3} \text { in } \mathrm{THF}\right)^{[5,9]}$ and converted to the transition metal complexes - an effective catalysts in oxidation reactions. ${ }^{[10]}$ The reduction processes involving corrolazines as reactants or products were studied only in non-aqueous solvents. Among water soluble corrolazines only tetrasulfonated tetrabenzocorrolazine was so far reported. ${ }^{[11,12]}$ It was found that sulfonated $\mathrm{P}^{\mathrm{V}}$ tetrabenzocorrolazine due to its enhanced abilities to generate ${ }^{1} \mathrm{O}_{2}{ }^{[13]}$ and to cleave DNA ${ }^{[14]}$ is a perspective dye for medical applications, e.g. as photosensitizer for photodynamic therapy.

Taking these issues into account the study of interaction of $\mathrm{P}^{\mathrm{V}}$ corrolazines in aqueous media with various reducing agents including natural reductants is of great interest.
Sodium dithionite is a strong S-containing reductant which is capable to reduce cobalamins ${ }^{[15]}$ - derivatives of the vitamin $B_{12}$ which play an important role in the natural biochemical processes as redox catalysts. ${ }^{[16]}$ While cobalamin $[\mathrm{Cbl}(\mathrm{III})]$ contains $\mathrm{Co}^{\mathrm{III}}$ in the coordination center of the corrin macrocyclic ligand, $\mathrm{Co}^{\mathrm{II}}$ and $\mathrm{Co}^{\mathrm{I}}$ are present in its reduced and super-reduced forms, [Cbl(II)] and [Cbl(I)], respectively. The catalytic cycle of aqua- and cyanocobalamins involve the reversible reduction of the central metal $\mathrm{Co}^{\mathrm{III}} \leftrightarrow \mathrm{Co}^{\mathrm{II}} \leftrightarrow \mathrm{Co}^{\mathrm{I}}{ }^{[17]}$ The reduced forms of cobalamin catalyzing the reduction of oxygen and reactive oxygen species $^{[18,19]}$ can therefore modulate the PDT activity of the photosensitizer.

We have prepared novel water soluble photosensitizer - N-methylated derivative of 2-pyridyl substituted $\mathrm{P}^{\mathrm{v}}$ corrolazine $\left[\left(\mathrm{Me}^{+} \mathrm{Py}\right)_{8} C A \mathrm{P}(\mathrm{OH})_{2}\right]\left(\mathrm{I}^{-}\right)_{8}$ (Scheme 1) and in the present preliminary communication we report that it can be reversibly reduced by $\mathrm{Na}_{2} \mathrm{~S}_{2} \mathrm{O}_{4}$ and by cobalamin $[\mathrm{Cbl}(\mathrm{I})]$.

Previously it was observed that reaction of aryl substituted porphyrazines $\left[\mathrm{Ar}_{8} \mathrm{PAH}_{2}\right]\left(\mathrm{Ar}=\mathrm{Ph},{ }^{[4]} 4\right.$-tert- $\left.\mathrm{BuPh}^{[5]}\right)$, with large excess of $\mathrm{PBr}_{3}$ in pyridine under reflux leads to contraction of porphyrazine macrocycle and formation of $\mathrm{P}^{\mathrm{V}}$ complexes of corrolazine $\left[(\mathrm{Py})_{8} C A \mathrm{P}=\mathrm{O}\right]$. We have used similar reaction conditions ${ }^{[4]}$ for preparation of 2-pyridiyl substituted $\mathrm{P}^{\mathrm{V}}$ corrolazine from the corresponding porphyrazine, $\left[\mathrm{Py}_{8} \mathrm{PAH}_{2}\right]$, obtained as described earlier ${ }^{[20,21]}$ and $\mathrm{PBr}_{3}$ (1:20 molar ratio). The crude $\mathrm{P}^{\mathrm{V}}$ corrolazine obtained as precipitate by pouring of the reaction mixture into water was dissolved in $\mathrm{CH}_{2} \mathrm{Cl}_{2}$, passed through silica column. The residue obtained after evaporation of the solvent was treated with $\sim 4$-fold excess of methyl iodide in

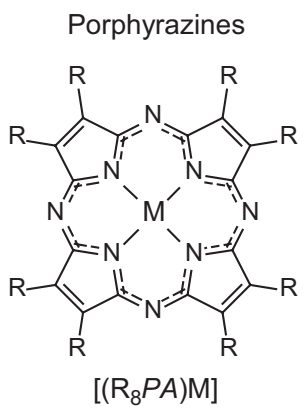

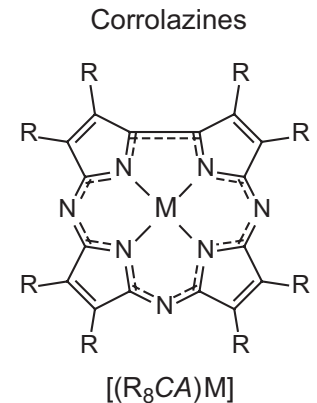

Tetrabenzocorrolazines

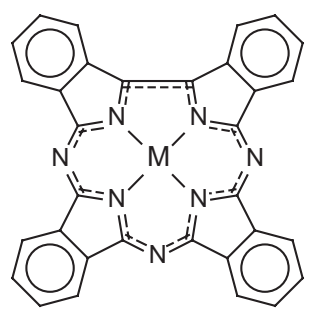

$[(T B C A) \mathrm{M}]$

Chart 1.

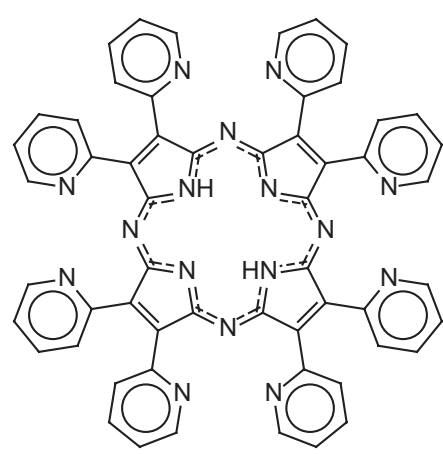

$\left[\mathrm{Py}_{8} \mathrm{PAH}_{2}\right]$

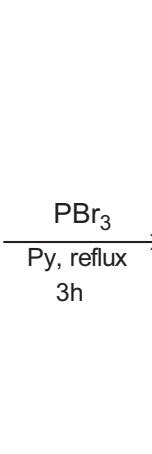

$3 \mathrm{~h}$

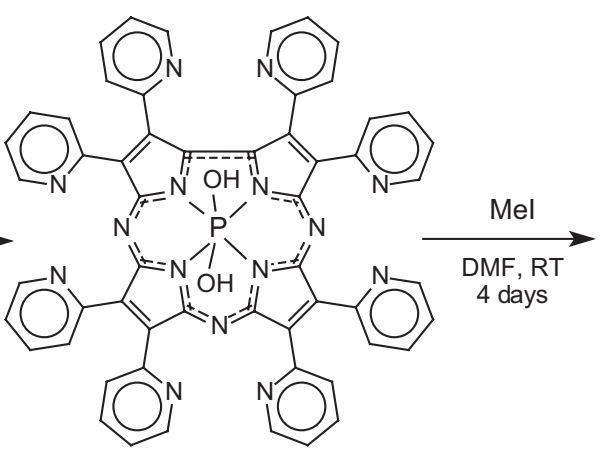

$\left[\mathrm{Py}{ }_{8} \mathrm{CAP}(\mathrm{OH})_{2}\right]$

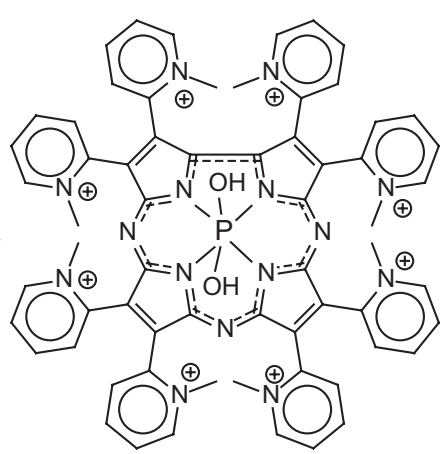

$\left[(\mathrm{Me}+\mathrm{Py})_{8} \mathrm{CAP}(\mathrm{OH})_{2}\right]$

Scheme 1. Synthesis of $N$-methylated 2-pyridyl substituted $\mathrm{P}^{\mathrm{V}}$ corrolazine 

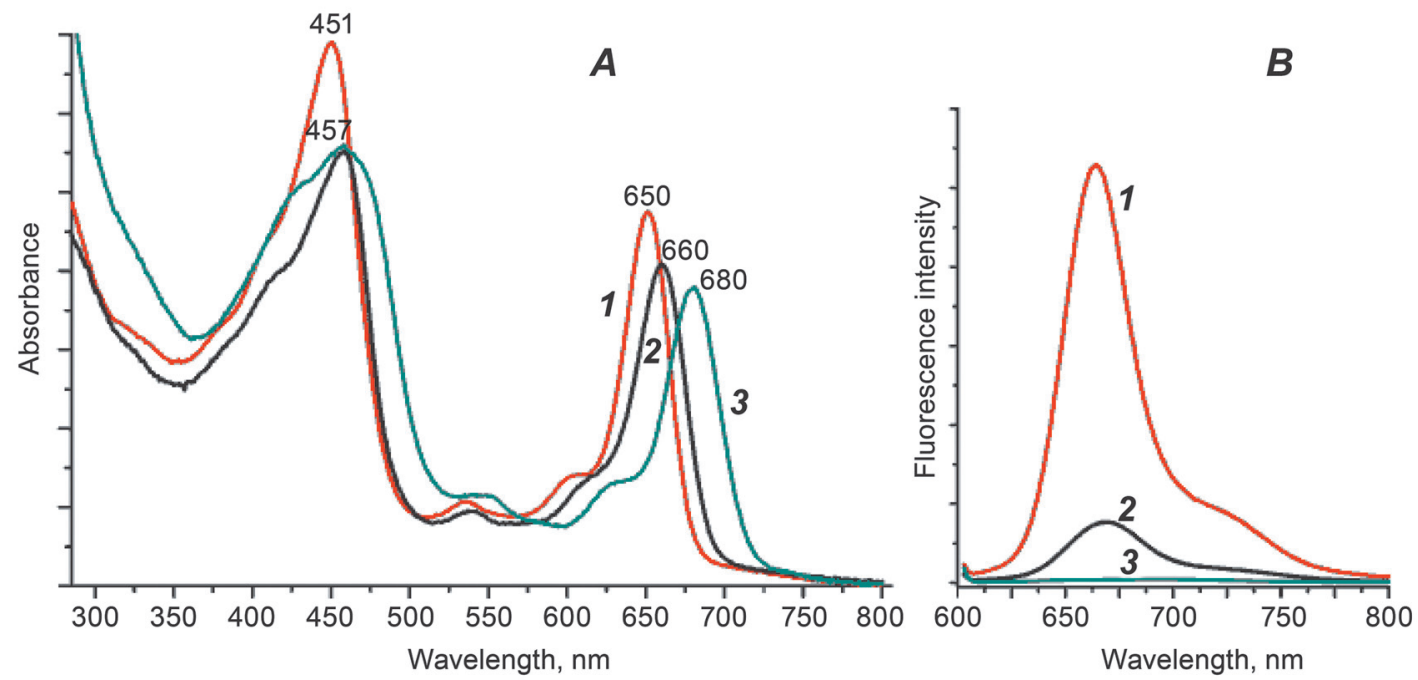

Figure 1. Electronic absorption $(A)$ and emission $(B)$ spectra of $\left[\left(\mathrm{Me}^{+} \mathrm{Py}\right)_{8} C A \mathrm{P}(\mathrm{OH})_{2}\right]$ in water at $\mathrm{p} H=4.0(1), 7.5(2)$ and $12(3)$.

DMF in conditions similar to that used for $N$-methylation of 2-pyridyl substituted porphyrazines. ${ }^{[22,23]}$ After mixing with toluene and staying in the refrigerator $N$-methylated $\mathrm{P}^{\mathrm{V}}$ corrolazine $\left[(\mathrm{Me}+\mathrm{Py})_{8} C A \mathrm{P}(\mathrm{OH})_{2}\right]$ was obtained as green iodide salt. It is well soluble in water and its ${ }^{31} \mathrm{P}$ NMR spectrum recorded in $\mathrm{D}_{2} \mathrm{O}$ contains the resonance signal at $-205 \mathrm{ppm}$, which is typical for hexacoordinated $\mathrm{P}^{\mathrm{V}}$ atom strongly shielded by $\pi$-ring current of the aromatic macrocycle. ${ }^{[24]}$ Electronic absorption spectrum of the neutral water solution contains an intense $\mathrm{Q}$ band at $660 \mathrm{~nm}$ and Soret band at $457 \mathrm{~nm}$ (Figure 1A, curve 2). Appearance of the Soret band at $440-460 \mathrm{~nm}$ is a typical feature confirming formation of corrolazine macrocycle, since in the corresponding porphyrazine complexes the maximum of this band is observed at $350-380 \mathrm{~nm}$. It is interesting that position of the Q band maxima in the absorption spectra depends on the $\mathrm{p} H$ of water solutions. The maximum of $\mathrm{Q}$ band observed at $660 \mathrm{~nm}$ in the neutral medium $(\mathrm{p} H=7.5)$, is shifted hypsochromically to $650 \mathrm{~nm}$ upon acidification (at $\mathrm{pH}=4.0$ ) and bathochomically to $680 \mathrm{~nm}$ upon increase of $\mathrm{pH}>9$ (Figure 1A, curves 1 and 3). These spectral changes are very likely connected with acid ionization of the central dihydrophosphonate moiety:

$$
\left\{\mathrm{P}(\mathrm{OH})_{2}\right\} \underset{\mathrm{H}^{+}}{\rightleftharpoons}\left\{\mathrm{P}\left(\mathrm{O}^{-}\right)(\mathrm{OH})\right\} \underset{\mathrm{H}^{+}}{\rightleftharpoons}\left\{\mathrm{P}\left(\mathrm{O}^{-}\right)_{2}\right\}
$$

It is interesting that fluorescence intensity strongly depends on $\mathrm{pH}$ and is practically completely quenched in basic medium (Figure 1B). Quenching of fluorescence can be explained by intramolecular electron transfer from the negatively charged oxygen atom in the anionic forms appearing in the basic media.

The addition of $\mathrm{Na}_{2} \mathrm{~S}_{2} \mathrm{O}_{4}$ to an aqueous solution of $\left[\left(\mathrm{Me}^{+} \mathrm{Py}\right)_{8} C A \mathrm{P}(\mathrm{OH})_{2}\right](\mathrm{p} H$ range $7.5-9.2)$ results in instantaneous color changes. Spectrophotometric titration experiment reveals two consecutive reduction steps (Figure 2).

In the first stage characterized by color change from green to yellow the absorption band of the initial corrolazine complex $\left[\left(\mathrm{Me}^{+} \mathrm{Py}\right)_{8} C A \mathrm{P}(\mathrm{OH})_{2}\right]$ at $660 \mathrm{~nm}$ disappears and new

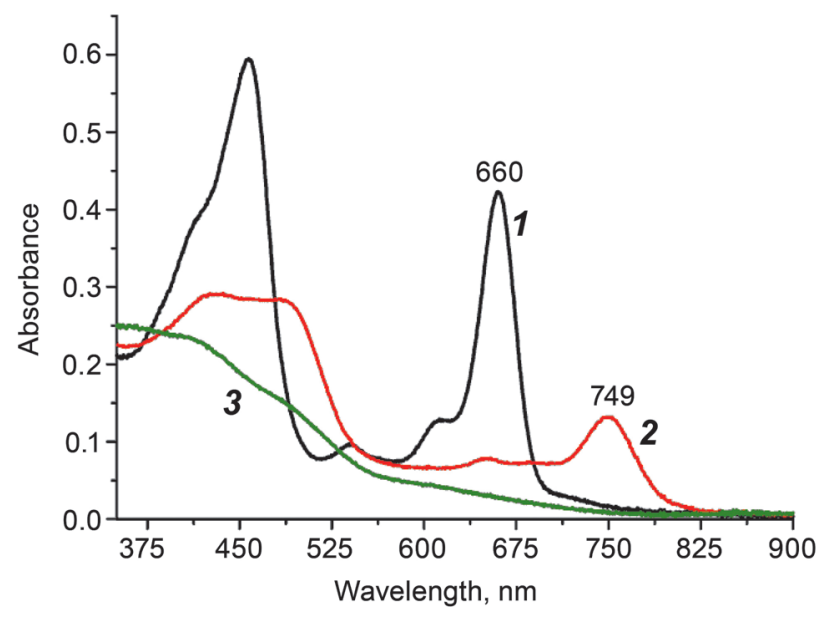

Figure 2. Electronic absorption spectra of water solutions of $\left[\left(\mathrm{Me}^{+} \mathrm{Py}\right)_{8} C A \mathrm{P}(\mathrm{OH})_{2}\right](10 \mu \mathrm{M})$ at $\mathrm{pH}=9.2(1)$ and its monoelectron (2) and two-electron (3) reduction products formed after addition of $\mathrm{Na}_{2} \mathrm{~S}_{2} \mathrm{O}_{4}(5 \mu \mathrm{M}(2)$ and $10 \mu \mathrm{M}(3))$.

broadened and less intense Q band appears at $749 \mathrm{~nm}$ (Figure 2, spectra 1 and 2). Such spectral changes are typical for the formation of monoreduced complexes of porphyrazinetype macrocycles. ${ }^{[22,25]}$ This process is fully completed at the $\left[\left(\mathrm{Me}^{+} \mathrm{Py}\right)_{8} C A \mathrm{P}(\mathrm{OH})_{2}\right]:\left[\mathrm{S}_{2} \mathrm{O}_{4}{ }^{2-}\right]$ ratio $=2: 1$. Following addition of dithionite up to $\left[\left(\mathrm{Me}^{+} \mathrm{Py}\right)_{8} C A \mathrm{P}(\mathrm{OH})_{2}\right]:\left[\mathrm{S}_{2} \mathrm{O}_{4}{ }^{2-}\right]$ ratio $=1: 1$ leads to brown color of the solution and all distinct absorption bands in the visible and near IR region disappear. This is typical for the $2^{\text {nd }}$ reduction of the macrocyclic chromophore in porphyrin-type complexes. ${ }^{[2,26]}$ The reduction of phosphorus atom $\left(\mathrm{P}^{\mathrm{V}} / \mathrm{P}^{\mathrm{III}}\right)$ in such conditions can be excluded. In the cases when reduction occurs on coordinating central atom the $\mathrm{Q}$ band should be retained. In the case of octaaryl substituted $\mathrm{P}^{\mathrm{V}}$ corrolazines the reduction occurs only by $\mathrm{Na} / \mathrm{NH}_{3}$ and leads to irreversible dephosphorylation. ${ }^{[9]}$

In contrast to the initial corrolazine complex $\left[(\mathrm{Me}+\mathrm{Py})_{8} C A \mathrm{P}(\mathrm{OH})_{2}\right]$ the reduced "yellow" and "brown" forms are not fluorescent. Both of them are stable and their 
spectra remain invariable in anaerobic conditions and room temperature at $\mathrm{pH} 7.0-9.2$ for at least 12 hours. When oxygen is bubbled through solutions of "yellow" and "brown" forms or they are exposed in the aerobic conditions their color turns again green and the electronic absorption and emission spectra of the initial complex $\left[\left(\mathrm{Me}^{+} \mathrm{Py}\right)_{8} C A \mathrm{P}(\mathrm{OH})_{2}\right]$ are completely recovered. This indicates that $\mathrm{P}^{\mathrm{V}}$ corrolazine is reversibly reduced by $\mathrm{Na}_{2} \mathrm{~S}_{2} \mathrm{O}_{4}$.

Sodium dithionite is a two-electron reducing agent, being oxidized to sulfite. ${ }^{[14]}$ Given the reversible character of the spectral changes, it could be assumed that upon dithionite action the consecutive formation of the products corresponding to one- and two-electron reduction of the $\pi$-chromophore is observed:

$$
\begin{aligned}
& 2\left[\left(\mathrm{Me}^{+} \mathrm{Py}\right)_{8} C A \mathrm{P}(\mathrm{OH})_{2}\right]+\mathrm{S}_{2} \mathrm{O}_{4}{ }^{2-}+2 \mathrm{H}_{2} \mathrm{O} \rightarrow \\
& \rightarrow 2\left[\left(\mathrm{Me}^{+} \mathrm{Py}\right)_{8} C A \mathrm{P}(\mathrm{OH})_{2}\right]^{\bullet-}+2 \mathrm{HSO}_{3}^{-}+2 \mathrm{H}^{+} \\
& \begin{array}{l}
2\left[\left(\mathrm{Me}^{+} \mathrm{Py}\right)_{8} C A \mathrm{P}(\mathrm{OH})_{2}\right]^{(-)}+\mathrm{S}_{2} \mathrm{O}_{4}{ }^{2-}+2 \mathrm{H}_{2} \mathrm{O} \rightarrow \\
\rightarrow 2\left[\left(\mathrm{Me}^{+} \mathrm{Py}\right)_{8} C A \mathrm{P}(\mathrm{OH})_{2}\right]^{2-}+2 \mathrm{HSO}_{3}^{-}+2 \mathrm{H}^{+}
\end{array}
\end{aligned}
$$

We have also studied the interaction of water soluble $\mathrm{P}^{\mathrm{V}}$ corrolazine with cyanocobalamin [(CN)Cbl(III)] and its reduced forms $[(\mathrm{Cbl}(\mathrm{II})]$ and $[\mathrm{Cbl}(\mathrm{I})]$ as natural reductants. When $[(\mathrm{CN}) \mathrm{Cbl}(\mathrm{III})]$ or $[\mathrm{Cbl}(\mathrm{II})]$ was added to neutral aqueous solution of $\left[\left(\mathrm{Me}^{+} \mathrm{Py}\right)_{8} C A \mathrm{P}(\mathrm{OH})_{2}\right]$ the resulting electronic absorption spectrum was a superposition of the spectra of the initial compounds and no spectral changes could be observed upon staying (Figure 3). However in the emission spectra some decrease of fluorescence intensity of $\mathrm{P}^{\mathrm{V}}$ corrolazine complex is observed in the presence of $[(\mathrm{CN})$ $\mathrm{Cbl}(\mathrm{III})]$. The absence of changes in the electronic absorption spectrum with simultaneous quenching of fluorescence might be indicative about $\pi$ - $\pi$ interaction between $\pi$-systems of corrolazine and cobalamin macrocycles. Formation of cobalamin $\pi$-complexes with other tetrapyrrolic macrocycles, e.g. iron porphyrins, was also observed. ${ }^{[27]}$

Addition of $\left[\left(\mathrm{Me}^{+} \mathrm{Py}\right)_{8} C A \mathrm{P}(\mathrm{OH})_{2}\right]$ to aqueous solution of super-reduced $\mathrm{B}_{12}$ leads to remarkable changes in its

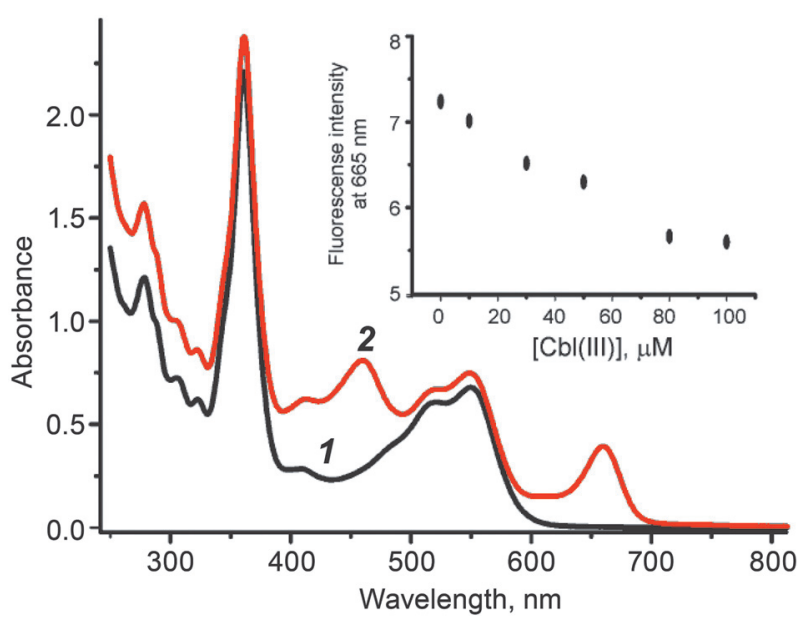

Figure 3. Electronic absorption spectra of cyanocobalamin $[(\mathrm{CN})$ $\mathrm{Cbl}(\mathrm{III})](1)$ and its mixture with $\left[\left(\mathrm{Me}^{+} \mathrm{Py}\right)_{8} \mathrm{CAP}(\mathrm{OH})_{2}\right](2)$ in water at $\mathrm{pH}=7.5$. Insert shows the dependence of fluorescence intensity at $665 \mathrm{~nm}$ on the concentration of [Cbl(III)].

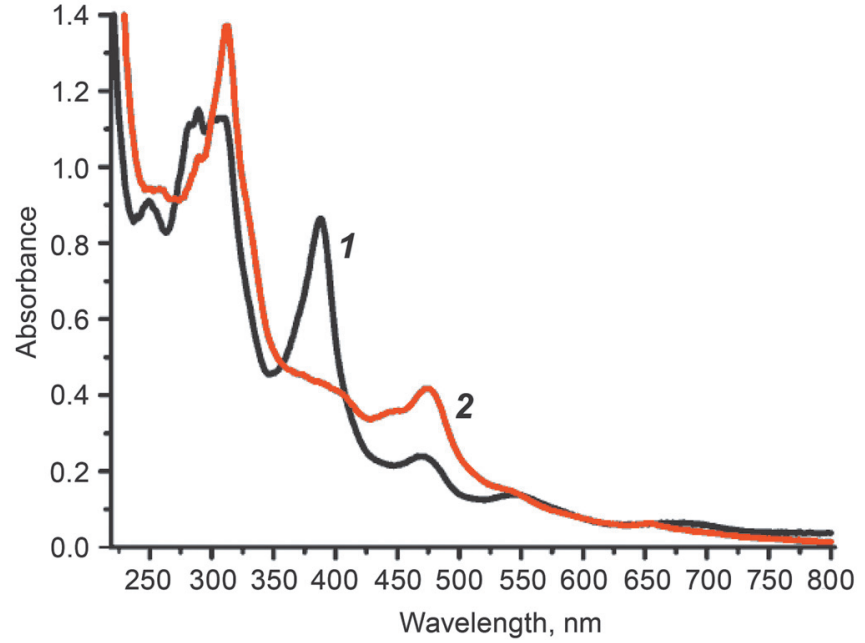

Figure 4. The spectral changes during the interaction of [Cbl(I)] with $\left[\left(\mathrm{Me}^{+} \mathrm{Py}\right)_{8} C A \mathrm{P}(\mathrm{OH})_{2}\right]$ in aqueous solution in anaerobic conditions $\left(\mathrm{p} H=7.5,25^{\circ} \mathrm{C}\right) .1$ - initial spectrum of $[\mathrm{Cbl}(\mathrm{I})]$ $(30 \mu \mathrm{M}), 2-$ after addition of $\left[\left(\mathrm{Me}^{+} \mathrm{Py}\right)_{8} C A \mathrm{P}(\mathrm{OH})_{2}\right](15 \mu \mathrm{M})$.

electronic absorption spectrum (Figure 4) accompanied by disappearance of the initial bands at 370 and $685 \mathrm{~nm}$ characteristic for $[\mathrm{Cbl}(\mathrm{I})]$ and appearance of new bands at 312 and $474 \mathrm{~nm}$ typical for [Cbl(II)]. This fact indicates a redox reaction between the corrolazine and super-reduced cobalamin complexes. The complete reduction of $\left[\left(\mathrm{Me}^{+} \mathrm{Py}\right)_{8} C A \mathrm{P}(\mathrm{OH})_{2}\right]$ requires 2 moles of $[\mathrm{Cbl}(\mathrm{I})]$. Since the peak at $750 \mathrm{~nm}$ characteristic for the first reduced form of $\mathrm{P}^{\mathrm{V}}$ corrolazine is absent in the final spectrum, the doubly reduced product is most likely formed:

$$
\begin{aligned}
{\left[\left(\mathrm{Me}^{+} \mathrm{Py}\right)_{8} C A \mathrm{P}(\mathrm{OH})_{2}\right]+2[\mathrm{Cbl}(\mathrm{I})] \rightarrow } & \rightarrow \\
& \rightarrow\left[\left(\mathrm{Me}^{+} \mathrm{Py}\right)_{8} C A \mathrm{P}(\mathrm{OH})_{2}\right]^{2-}+2[\mathrm{Cbl}(\mathrm{II})]
\end{aligned}
$$

$\left[\left(\mathrm{Me}^{+} \mathrm{Py}\right)_{8} C A \mathrm{P}(\mathrm{OH})_{2}\right]$ can be reduced by $[\mathrm{Cbl}(\mathrm{I})]$, but not by $[\mathrm{Cbl}(\mathrm{II})]$. It is known that redox potentials [Cbl(II)/(III)] and $[\mathrm{Cbl}(\mathrm{I}) /(\mathrm{II})]$ are 0.0 and $-0.85 \mathrm{~V}$ vs. $\mathrm{Ag} / \mathrm{AgCl}$, respectively. ${ }^{[28]}$ This means that potentials of the first and second reduction of the macrocycle for $\left[\left(\mathrm{Me}^{+} \mathrm{Py}\right)_{8} C A \mathrm{P}(\mathrm{OH})_{2}\right]$ should be observed in the range from 0.0 to $-0.85 \mathrm{~V} v s$. $\mathrm{Ag} / \mathrm{AgCl}$. For octaaryl substituted $\mathrm{P}^{\mathrm{V}}$ corrolazines $\left[\mathrm{Ar}_{8} C A \mathrm{P}(\mathrm{OMe})_{2}\right]$ (Ar = 4-tert-butylphenyl, 4-metoxyphenyl) the $1^{\text {st }}$ reduction of the macrocycle at $-0.8 \mathrm{~V}$ was followed by $\mathrm{P}^{\mathrm{V}} / \mathrm{P}^{\mathrm{III}}$ couple at $-1.33 \mathrm{~V}^{[5,9]}$ Since 2-pyridyl groups have the stronger acceptor properties which are additionally enhanced by their quaternization it is not surprising that two first reductions of the macrocycle in $\left[\left(\mathrm{Me}^{+} \mathrm{Py}\right)_{8} C A \mathrm{P}(\mathrm{OH})_{2}\right]$ are observed at less negative potentials than $\mathrm{P}^{\mathrm{V}} / \mathrm{P}^{\mathrm{III}}$ couple. Indeed the $1^{\text {st }}$ and $2^{\text {nd }}$ reductions of the macrocycle in the case of metal-free 2-pyridyl substituted porphyrazine $\left[\mathrm{Py}_{8} P A \mathrm{H}_{2}\right]$ are observed at -0.26 and $-0.65 \mathrm{~V} v s$. SCE in pyridine, ${ }^{[20]}$ and quaternization of 2-pyridyl groups facilitates the $1^{\text {st }}$ and $2^{\text {nd }}$ reduction of porphyrazine macrocycle by $0.15-0.25 \mathrm{~V} .^{[26]}$

Interaction of reduced forms of $\mathrm{P}^{\mathrm{V}}$ corrolazine with cobalamins was also studied. The double reduced form $\left[\left(\mathrm{Me}^{+} \mathrm{Py}\right)_{8} C A \mathrm{P}(\mathrm{OH})_{2}\right]^{2-}$ does not react with cyanocobalamin $[(\mathrm{CN}) \mathrm{Cbl}(\mathrm{III})]$ which has the reduction potential $\mathrm{Co}^{\mathrm{III}} / \mathrm{Co}^{\mathrm{I}}$ at $-1.00 \mathrm{~V} \cdot{ }^{[29]}$ However aquacobalamin $\left[\left(\mathrm{H}_{2} \mathrm{O}\right) \mathrm{Cbl}(\mathrm{III})\right]$ having 


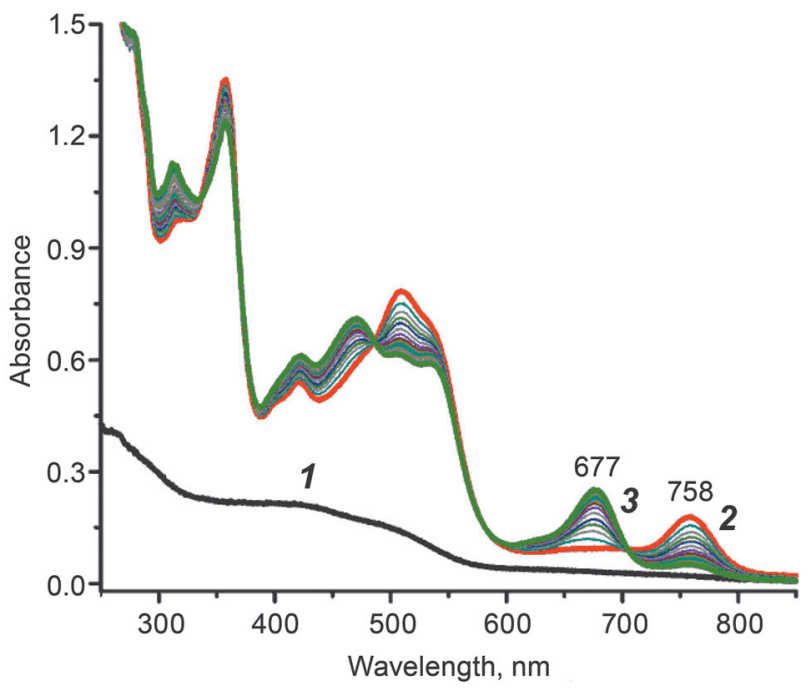

Figure 5. Interaction of doubly reduced $\mathrm{P}^{\mathrm{V}}$ corrolazine with aquacobalamin in aqueous solution $\left(\mathrm{p} H=12.4,25^{\circ} \mathrm{C}\right.$, anaerobic conditions). 1 - initial spectrum of $\left[\left(\mathrm{Me}^{+} \mathrm{Py}\right)_{8} C A \mathrm{P}(\mathrm{OH})_{2}\right]$ $(6.5 \mu \mathrm{M}), 2 \rightarrow 3-$ spectral changes observed after addition of $\left[\left(\mathrm{H}_{2} \mathrm{O}\right) \mathrm{Cbl}(\mathrm{III})\right](80 \mu \mathrm{M}, 2-0,3-15 \mathrm{~min})$.

much more positive reduction potentials $\left(\mathrm{Co}^{\mathrm{III}} / \mathrm{Co}^{\mathrm{II}}\right.$ at $0.0 \mathrm{~V}$ and $\mathrm{Co}^{\mathrm{II}} / \mathrm{Co}^{\mathrm{I}}$ at $\left.-0.85 \mathrm{~V}^{[28]}\right)$ can easily oxidize the reduced forms of $\mathrm{P}^{\mathrm{V}}$ corrolazine. Thus, when excess of $\left[\left(\mathrm{H}_{2} \mathrm{O}\right)\right.$ $\mathrm{Cbl}(\mathrm{III})]$ is added to aqueous solution of the double reduced form $\left[\left(\mathrm{Me}^{+} \mathrm{Py}\right)_{8} C A \mathrm{P}(\mathrm{OH})_{2}\right]^{2-}$ one can observe its immediate reduction to a single reduced form $\left[\left(\mathrm{Me}^{+} \mathrm{Py}\right)_{8} C A \mathrm{P}(\mathrm{OH})_{2}\right]^{-}$ characterized by Q band at $758 \mathrm{~nm}$ (Figure 5, spectra 1 and 2). This process is followed by slower reduction step leading to disappearance of the band at $758 \mathrm{~nm}$ and appearance of the $\mathrm{Q}$ band at $677 \mathrm{~nm}$ typical for non-reduced $\mathrm{P}^{\mathrm{V}}$ corrolazine existing in strongly basic medium $(\mathrm{pH}=12.4)$ as deprotonated form of $\left[\left(\mathrm{Me}^{+} \mathrm{Py}\right)_{8} C A \mathrm{P}\left(\mathrm{O}^{-}\right)_{2}\right]$. Each step requires 1 equivalent of $\left[\left(\mathrm{H}_{2} \mathrm{O}\right) \mathrm{Cbl}(\mathrm{III})\right]$ as an oxidizer.

In conclusion, we have prepared new water soluble $\mathrm{P}^{\mathrm{V}}$ corrolazine complex bearing $N$-methyl-2-pyridiniumyl groups and studied its behavior in basic aqueous solutions. In the presence of sodium dithionite corrolazine macrocycle is reversibly reduced in basic medium forming consequently single and double reduced $\pi$-anionic forms, while reduction of the coordinated $\mathrm{P}^{\mathrm{V}}$ atom is not observed. $\mathrm{P}^{\mathrm{V}}$ Corrolazine participates in $\pi$-interaction with cobalamins, e.g with $[(\mathrm{CN}) \mathrm{Cbl}(\mathrm{III})]$, while the super-reduced form of vitamin $\mathrm{B}_{12},[\mathrm{Cbl}(\mathrm{I})]$, reduces it with formation of $\pi$-dianion, which in turn can be oxidized by aquacobalamin. It was also observed that central phosphonate moiety can be deprotonated in basic medium. The obtained results indicate that $\mathrm{P}^{\mathrm{V}}$ corrolazine can be used as a mediator for catalytic processes involving cobalamins in basic medium, and the further results will be reported in due course.

Acknowledgments. The work was supported by Russian Science Foundation (grant No. 17-13-01522).

\section{References}

1. Breusova M.O., Pushkarev V.E., Tomilova L.G. Russ. Chem. Bull. 2007, 56, 1456-1460.

2. Zhang, X.-F. Coord. Chem. Rev. 2015, 285, 52-64.

3. Li J., Subramanian L.R., Hanack M. Eur. J. Org. Chem. 1998, 2759-2767.

4. Ivanova S.S., Moryganova Yu., Hamdoush M., Koifman O.I., Sal'nikov D.S., Stuzhin P.A. J. Porphyrins Phthalocyanines 2014, 18, $875-883$.

5. Ramdhanie B., Stern C.L., Goldberg D.P. J. Am. Chem. Soc. 2001, 123, 9447-9448.

6. Fujiki M., Tabei H., Isa K. J. Am. Chem. Soc. 1986, 108, 1532-1536.

7. Myakov V.N., Kurskii Yu.A., Sedel'nikova V.N., Makhrova T.V., Lopatin M.A. Russ. J. Coord. Chem. 2008, 34, 522-526.

8. Raboui H., Lough A.J., Szawiola A.M., Bender T.P. Inorg. Chem. 2018, 57, 5174-5182.

9. Joslin E.E., Zaragoza J.P.T., Baglia R.A., Siegler M.A., Goldberg D.P. Inorg. Chem. 2016, 55, 8646-8660.

10. Goldberg D.P. Acc. Chem. Res. 2007, 40, 626-634.

11. Song Z., Zhang F., Lia X., Shek-Kiu C., Zhao F., Tang Y. J. Porphyrins Phthalocyanines 2002, 6, 484-488.

12. Lapok L., Schnurpfeil G., Gerdes R., Gorun S.M., Suvorova O., Kudryavtseva G.S., Woehrle D. J. Porphyrins Phthalocyanines 2009, 13, 346-357.

13. Song Z., Zhang F., Li X., Shek-Kiu Ch., Zhao F., Tang Y. J. Porphyrins Phthalocyanines 2002, 6, 484-488.

14. Huang L., Zhao P., Li Z., Zhang F., Tung C.-H. J. Phys. Chem. A 2008, 112, 4165-4169.

15. Huang L., Zhong C., Zhang F., Tung C.-H. Bioorg. Med. Chem. Lett. 2008, 18, 2152-2155.

16. Salnikov D.S., Silaghi-Dumitrescu R., Makarov S.V., van Eldik R., Boss G.R. Dalton Trans. 2011, 40, 9831-9834.

17. Dereven'kov I.A., Salnikov D.S., Silaghi-Dumitrescu R., Makarov S.V., Koifman O.I. Coord. Chem. Rev. 2016, 309, 68-83.

18. Salnikov D.S., Makarov S.V.New J. Chem. 2019, 43, 7708-7715.

19. Suarez-Moreira E., Yun J., Birch C.S., Williams J.H.H., McCaddon A., Brasch N.E. J. Am. Chem. Soc. 2009, 131, 15078-15079.

20. Salnikov D.S., Makarov S.V., Koifman O.I. New J. Chem. 2020, Advance Article, doi: 10.1039/D0NJ04231E

21. Sciscione F., Cong L., Donzello M.P., Viola E., Ercolani C., Kadish K.M. Inorg. Chem. 2017, 56, 5813-5826.

22. Donzello M.P., De Mori G., Viola E., Ercolani C., Ricciardi G., Rosa A. Inorg Chem. 2014, 53, 8009-8019.

23. Bergami C., Donzello M.P., Ercolani C., Monacelli F., Kadish K.M., Rizzoli C. Inorg. Chem. 2005, 44, 9852-9861.

24. Sciscione F., Manoli F., Viola E., Wankar J., Ercolani C., Donzello M.P., Manet I. Inorg. Chem. 2017, 56, 12795-12808.

25. Akiba K., Nadano R., Satoh W., Yamamoto Y., Nagase S., Ou Z., Tan X., Kadish K.M. Inorg. Chem. 2001, 40, 5553-5567.

26. Ivanova S.S., Stuzhin P.A. J. Porphyrins Phthalocyanines 2011, 15, 1299-1309.

27. Bergami C., Donzello M.P., Monacelli F., Ercolani C., Kadish K.M. Inorg. Chem. 2005, 44, 9862.

28. Chemaly S.M., Chen C.-T., van Zyl R.L. J. Inorg. Biochem. 2007, 101, 764-773.

29. Salnikov D.S., Kucherenko P.N., Dereven'kov I.A., Makarov S.V., van Eldik R. Eur. J. Inorg. Chem. 2014, 2014, 852-862.

30. Lexa D., Savant J.M., Zickler J. J. Am. Chem. Soc. 1980, 102, 2654-2663. 